\title{
Polyurethane Foam in a Reliable Method for Electrophoretic Separation of Proteins
}

\author{
Loai Aljerf ${ }^{*}$, Farouk Dehmchi², Viet Ty Pham³ ${ }^{3}$ Ala Eldin Choukaife ${ }^{4}$ \\ ${ }^{1}$ Independant, Damascus, Syria. \\ ${ }^{2}$ Chemistry Department, Badji Mokhtar University, Annaba, Algeria. \\ ${ }^{3}$ Department of Chemistry, Hue University of Education, 34 Le Loi street, Hue city, Vietnam. \\ ${ }^{4}$ Department of Life Sciences, Faculty of Dentistry, Syrian Private University, Damascus, Syria. \\ *envirochrom@hotmail.com
}

\begin{abstract}
Little information about the possible use of foamed polyurethane sponge as an auxiliary phase in electrophoresis is barely published. In the current work, pieces of sponge have been segmented and filled predescribed horizontal and vertical cells. A well-designed system has been introduced to save an easy retrieval of free-contaminated products with latitudes used in inspecting the migration over heterogeneous lanes. In the current work, the troughs were filled with the loaded segments of flexible polyurethane foam. The cells were involved in the experiments of zone electrophoresis and isoelectric migration engaging albumin, serum, and provisions of human prostatic acid phosphatase. Some or all the following parameters: Density, $\mathrm{pH}$, and ionic strength, have been experienced in the present application of the segmental sponge system in electrophoretic experimentations. The better preparations containing phosphatase were 50 to 100 times more active per mg than the initial extract of prostate gland from which they had been secluded. Protein richest in enzyme was situated in the zone of high content of acetate at $\mathrm{pH}$ 4.15. As a result of diffusion in unfilled sponges, the protein movement was hindered. Surprisingly, no droplets have been noticed in the sponge system thru zone electrophoresis in a sucrose density gradient. Consequently, this study can be useful to researchers studying protein changes resulting from genetic mutation, development, drug treatment or disease, in neural tissue as well as in virtually all other tissues.
\end{abstract}

Keywords: Isoelectric migration, Prostatic acid phosphatase, Ionic strength, Prostate gland, Plasticizer, Electric field.

\section{INTRODUCTION}

Proteins are used in such industrial and clinical applications [1-3]; however, their separations are still a major challenge. In this field, different chromatographic methods used to separate and to purify protein or (more often) peptide in solution based on size, charge or overall hydrophobicity as size exclusion chromatography, sodium dodecyl sulfate-polyacrylamide gel electrophoresis (SDS-PAGE), gel permeation chromatography (GPC), affinity chromatography (AC), hydrophobic interaction chromatography (HIC), ion exchange chromatography (IEC), reversed phase chromatography (RPC), and high performance liquid chromatography (HPLC) [4-8]. Other teams also used magnetic [9] and electrophoresis to purify proteins [10,11].

Electrophoresis meaning "to bear electrons" is the motion of dispersed particles relative to fluid under the influence of as spatially uniform electric field. Electrophoresis of positively charged particles (cations) is sometimes called cataphoresis, while electrophoresis of negatively charged particles (anions) is sometimes called anaphoresis. Nowadays, electrophoresis is used in laboratories to separate macromolecules based on size. The technique applies a negative charge so proteins move towards a positive charge. Therefore, electrophoresis is used extensively in DNA, RNA, and protein analysis [12,13]. 
Polyurethane Foam in a Reliable Method for Electrophoretic Separation of Proteins

Such gels used in electrophoresis are prepared by heating and cooling a quantity of partially hydrolyzed starch in an appropriate buffer solution [14]. Besides, starch gelatinization is a process of breaking down the intermolecular bonds of starch molecules in the presence of water and heat, allowing the hydrogen bonding sites to engage more water. This irreversibly dissolves the starch granule in water. Water acts as a plasticizer [15].

Preliminary efforts to isolate human prostatic acid phosphatase (PAP, also named prostatic specific acid phosphatase, is an enzyme produced by the prostate. It may be found in increased amounts in men who have prostate cancer or other diseases. The highest levels of acid phosphatase are found in metastasized prostate cancer.) by electrophoresis with starch gel as the supporting medium $[16,17]$ gave a productheavily contaminated with soluble starch and protein. In an attempt to avoid such contamination, it was decided to investigate the possibility of substituting an inert flexible plastic foam for the starch gel. Besides, avoiding the introduction of extraneous matter, the spongy matrix offered the additional advantage of permitting electrophoresis in a segmental system.

Such a system composed of a series of contiguous segments of sponge could be used to study migration not only within a medium of uniform composition but also along a pathway of heterogeneous composition. With a cell so constructed, it should be possible to study without difficulty the influence of variables like $\mathrm{pH}$, ionic strength and density separately or simultaneously. The fact that an uncontaminated product might be easily recovered by squeezing out the contents of each segment separately opened these attractive possibilities to investigation. Accordingly, experiments have been done to explore these possibilities and the results which demonstrate the potentialities of polyurethane (PU) foam in such investigations are reported in detail.

\section{Materials And Methods}

\section{Polyurethane Foam}

The plastic foam used in these experiments was preferably of the smallest port size stocked by the National Foam and Rubber Co., Boston, Mass. Rectangular segments could be cut by hand most conveniently from the dry plastic with a Stadie blade \#7120-D (Arthur H. Thomas Co., Phila., PA). Disks of foam were stamped out of sheeting by the Palais Die Cut-Outs Company, Boston, Mass.

\section{Horizontal Cell}

Several different horizontal cells were employed. The standard cell was made from five strips of $3.18 \mathrm{~mm}$ thick Plexiglass (Poly (methyl methacrylate), also known as acrylic or acrylic glass, as well as by the trade names Crylux, Acrylite, Lucite, and Perspex among several others, is a transparent thermoplastic often used in sheet form as a lightweight or shatter-resistant alternative to glass.) of the following dimensions: one piece $304 \times$ $50.8 \mathrm{~mm}$, two pieces $304 \times 12.7 \mathrm{~mm}$, and two pieces $50.8 \times 12.7 \mathrm{~mm}$.

The above pieces were cemented together with Plexiglass Cement (Transplastics Co. of Boston) to form a trough measuring $304 \mathrm{~mm}$ long $\times 43.4 \mathrm{~mm}$ wide $\times 12.7 \mathrm{~mm}$ high. The two small pieces on the end were attached 2.0 $\mathrm{mm}$ above the level of the base of the trough so as to accommodate a loop of filter paper (Whatman 3). The wet paper served as a bridge to the buffer in a 250 -ml beaker containing a silver chloride $(\mathrm{AgCl})$ electrode (PerkinElmer). In addition to the electrode, each buffer vessel contained $20 \mathrm{ml}$ of a solution of $12 \%$ sodium chloride $(\mathrm{NaCl})$ in water which was layered beneath $200 \mathrm{ml}$ of buffer solution. Some experiments were made using a cell with a trough $400 \mathrm{~mm}$ long $\times 40.5 \mathrm{~mm}$ wide $\times 12.7 \mathrm{~mm}$ high. The latter cell was of one piece with its electrode vessels. The end sections of sponge were cut in the shape of the letter $L$, one end of which dipped into the buffer solution of the electrode vessels, thus replacing the filter paper bridges. For work with micro amounts of protein, a horizontal cell with a trough measuring $304 \mathrm{~mm} \times 5.0 \mathrm{~mm} \times 10.0 \mathrm{~mm}$ was also constructed.

The individual segments of sponge were filled by holding them below the surface of the liquid and repeatedly squeezing them to remove as much trapped air as possible. When a number of segments were to be filled with 
the same buffer, it was more convenient to put them into a beaker of buffer solution and heat the mixture to boiling. After the air had been driven out by this means, the sections of sponge readily filled with liquid on cooling. In assembling the cell, first the paper bridges wetted with buffer solution were looped over the end pieces and then the central section was built up by filling the trough with the loaded segments of flexible PU foam. The segment containing the solution of protein was generally added last after temperature equilibrium had been reached.

Next, the horizontal cell was placed on a test tube rack in the refrigerator, the bridges of filter paper were dipped into the buffer vessels, and the central section holding the sponges was covered with a piece of glass. Leads from an external constant voltage power supply (Heathkit Co. or Research Specialties Co.) were clipped to the silver chloride $(\mathrm{AgCl})$ electrodes and the temperature of the refrigerator was kept at $5^{\circ}$.

To empty the horizontal cell at the end of the run, the individual sponges were lifted out with a spatula and slid into a syringe. The contents of the sponge were then squeezed out into a numbered graduated conical centrifuge tube. The last trace of the contents could be removed by rinsing the section with fresh solution. A small amount of debris torn from the sponge readily settled on centrifugation.

\section{Vertical Cell}

The vertical apparatus (Figure 1) consisted first of a $250 \mathrm{ml}$ Erlenmeyer flask which served as one electrode vessel. The flask was fitted with a two-holed rubber stopper in one hole of which was an AgCl electrode sealed with Pyseal Cement (Macalester) (\#C-228, Fisher Scientific, Pittsburg, PA). The second hole contained a glass tube topped by the inner connection of a standard taper ground glass joint (size 29/26). The inner connection had been fitted originally with a perforated plate. The central portion of this plate had been cut out with a vibrating tool to leave only an inner rim which served to support the column of sponges.

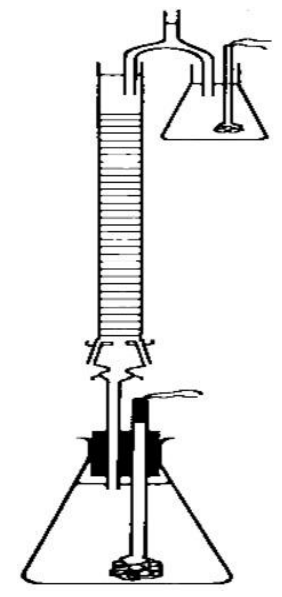

Fig1. Vertical cell

Assembly of the cell was begun first with the lower electrode vessel. Thus, buffer solution was put into the Erlenmeyer flask so that with the stopper in place liquid, was just forced upward into the glass tube. Then, 20 $\mathrm{ml}$ of $12 \% \mathrm{NaCl}$ were introduced through the joint with a long needle reaching to the bottom of the flask. At this point, if the level of liquid did not cover the sponge supporting rim, after the contents had been cooled to $5^{\circ}$, additional buffer solution was supplemented as required.

Next, a glass column $230 \mathrm{~mm}$ long with a matching 29/26 standard taper joint was placed securely on the inner piece, and then filled with disks of sponge containing liquid of the desired composition. The column of buffer extending from the interior of the flask to the top of the inner connection served as a bridge between the lower electrode vessel and the sponges. 
Polyurethane Foam in a Reliable Method for Electrophoretic Separation of Proteins

Certain precautions had to be observed in assembling and disassembling the column of sponges in the vertical cell. Because the vertical cell is basically only a column of liquid, it was necessary to add additional liquid after inserting each disk of sponge in order to raise the level of liquid in the column to the upper edge of the disk. The additional liquid was needed to compensate for the space not filled by the sponge and its contents as well as for whatever liquid was lost from the sponge as it brushed against the inner wall of the glass column during insertion. In this connection, it was also necessary to wipe off the inner wall occasionally in order not to contaminate succeeding sections that were to be placed higher up in the cell. At the end of the run, the contents of each disk were collected separately. Most of the liquid from each section was expressed within the column in situ so that the segment of sponge was moderately dry before withdrawal. This procedure was adopted to avoid losses that always occurred when a liquid-laden section touched the inner wall of the glass column as the sponge was being withdrawn. The expressed liquid remaining in the column was aspirated by a syringe fitted with a long needle and was added to whatever residual liquid could be squeezed from the withdrawn segment. A convenient tool used both in setting up and taking down the column was a piece of glass tubing $500 \mathrm{~mm}$ long, one end of which was closed off as a small sharp hook for manipulating the disks while the other held a wad of absorbent paper for drying the inside wall of the column.

After the requisite number of sponges had been inserted, the rest of the column was filled with buffer solution. At this point in the procedure, the apparatus was placed in the refrigerator and clamped to a ring stand for support. A second Erlenmeyer flask containing buffer and salt solutions and an AgCl electrode was placed adjacent to the top of the column and supported on a second stand. The bridge between the liquid at the top of the column and that in the upper electrode was established by simultaneously drawing buffer solution into two arms of a U-tube from the column on one side and from the flask on the other. When the intersection of the U-tube had filled with buffer solution and the bridge was formed, the third arm was clamped shut, thus holding the liquid bridge in place.

\section{RESULTS}

Studies were carried out with pooled human serum, bovine crystalline albumin (Armour) and preparations of human prostatic phosphatase (PAcP) at various levels of purity. The better preparations containing phosphatase were 50 to 100 times more active per mg than the initial extract of prostate gland from which they had been isolated [18-20]. Solutions of proteins were dialyzed against the appropriate buffer solution for at least $18 \mathrm{~h}$ before electrophoresis.

The buffer solutions listed below were used in the experiments with serum. The composition of the buffer solutions used in other experiments is given most conveniently in the description of the relevant experiment.

\section{Veronal-Sodium Citrate, 0.1 Ionic Strength, PH 8.7}

Veronal is a brand name of a pure acid of barbital $\left(\mathrm{C}_{8} \mathrm{H}_{12} \mathrm{~N}_{2} \mathrm{O}_{3}\right)$. It was used as a sleeping aid from 1903 until the mid-1950s.

One liter of buffer solution contained: $12.37 \mathrm{~g}$ of sodium barbital $\left(\mathrm{C}_{8} \mathrm{H}_{11} \mathrm{~N}_{2} \mathrm{NaO}_{3}\right), 1.47 \mathrm{~g}$ of sodium citrate $\left(\mathrm{Na}_{3} \mathrm{C}_{6} \mathrm{H}_{5} \mathrm{O}_{7} \cdot 2 \mathrm{H}_{2} \mathrm{O}\right)$ and $0.521 \mathrm{~g}$ of citric acid $\left(\mathrm{C}_{6} \mathrm{H}_{8} \mathrm{O}_{7} \cdot \mathrm{H}_{2} \mathrm{O}\right)$ and water. This buffer was employed for the standard boundary electrophoresis and the results are presented later in Figures 8 and 9.

\section{Tris-Citrate, 0.1 Ionic Strength, PH 8.8}

One (1) contained $30.33 \mathrm{~g}$ tris-(hydroxymethyl)-aminomethane $\left(\left(\mathrm{HOCH}_{2}\right)_{3} \mathrm{CNH}_{2}\right), 3.5 \mathrm{~g}$ citric acid $\cdot \mathrm{H}_{2} \mathrm{O}$ and water. This buffer diluted 3 parts to 7 of water, was employed in the sponge electrophoresis of serum (Figure 2). Protein was determined turbidimetrically by the method of Rios [21] and acid phosphatase by the phenol liberated from phenyl phosphate using charcoal under conditions described elsewhere [22]. 


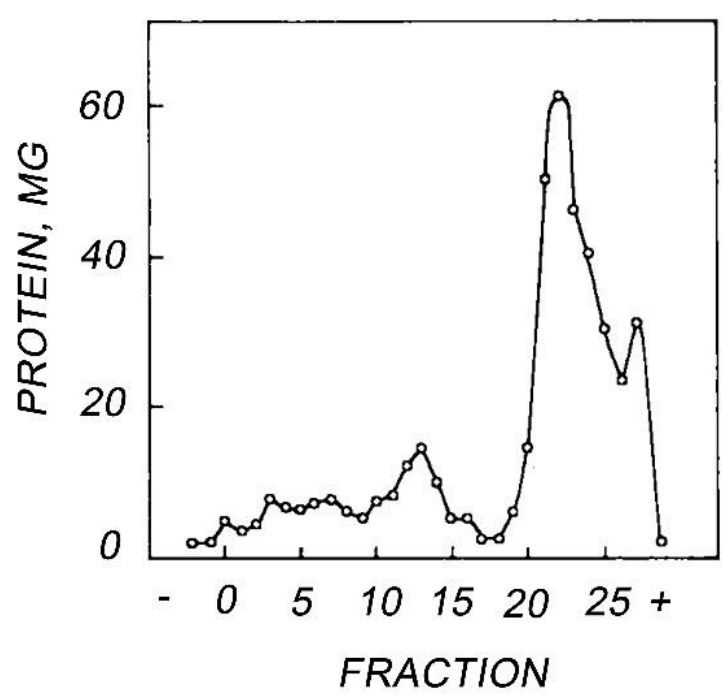

Fig2. Horizontal zone electrophoresis of pooled human serum. $400 \mathrm{mg}$ of protein in $5 \mathrm{ml}$ of serum dialyzed against 0.03 ionic strength Tris-citrate, $\mathrm{pH} 8.8$, were placed in a section of sponge $5 \mathrm{~cm}$ from the cathodic edge of the cell. The rest of the sponges contained 0.03 ionic strength Tris-citrate butler. Total fields, $5800 \mathrm{~V}$-h. Each fraction represents a segment $1 \mathrm{~cm}$ in width

\section{Horizontal Zone Electrophoresis of Serum}

The distribution of protein from pooled human serum at the end of a run lasting $21.5 \mathrm{~h}$ is shown in Figure 2. The voltage was gradually lowered during the first $10 \mathrm{~h}$ of the run-in order to maintain a current of $7 \mathrm{~mA}$. For this reason, the strength of the field is expressed in terms of the V-h unit which amounted to about 5800 in this case. The current rose to $50 \mathrm{~mA}$ by the end of the run, probably because of diffusion of salt into the cell proper from the electrode vessels.

The protein pattern was reminiscent of the one generally seen with normal human serum in boundary electrophoresis. Although, no proteins migrated into the electrode vessels, some moved onto the anodic filter paper bridge and accounted for the peak in advance of the major one.

Other experiments on the migration of serum in the horizontal cell indicated that the distribution of protein was determined by a combination of influences. For instance, under the same conditions as those obtaining in the experiment of Figure 2, more protein could be retained near the cathodic side simply by disturbing the salt layer in the cathodic vessel and thus hastening diffusion of salt into the cell. The resulting increase in conductivity tended to retard migration of the protein in that vicinity. Similar effects could be induced at the other end of the cell by stirring up the salt solution in the anodic vessel.

In addition, peaking of protein has been observed under other circumstances. When two contiguous segments of sponge were of different porosities and neither was completely filled, liquid was drawn by capillary action into the segment with the greater porosity (smaller pores). Although, two such contiguous segments may have contained solutions at the same concentration of protein, more protein was found in the segment with the smaller pores because it held the greater volume of liquid. This phenomenon would sometimes account for the peaks and depressions observed in a plot of total protein per sponge against $\mathrm{mg}$ of protein $/ \mathrm{cm}$ and could be avoided by using sponge of uniform capillarity throughout the length of the cell. However, it is conceivable that the principle of this phenomenon may be used to introduce liquid constrictions into the cell without having to change the shape of the horizontal apparatus. 
Polyurethane Foam in a Reliable Method for Electrophoretic Separation of Proteins

An additional feature that had to be taken into account especially in the electrophoresis of undiluted serum was the movement of material, simply because of differences in density of solutions in contiguous segments. By using sucrose $\left(\mathrm{C}_{12} \mathrm{H}_{22} \mathrm{O}_{11}\right)$ to equalize the density of the buffer solution with that of serum, it was possible to decrease the spreading of dense solutions of protein often observed in aged sponge. In this connection, better control of spreading appeared possible in a vertical column stabilized by a density gradient, vide infra.

Diffusion from the starting segment of dense solutions of protein began immediately in old sponge. Such movement without the application of an electric field seemed to be inhibited in new or unused polyurethane foam probably because of the hydrophobic finish on the surface of the material. Microscopic observations have shown that after repeated use, the plastic material contained fewer cell facings and fewer residual, unfoamed particles of polyurethane than fresh foam. Also, with reference to diffusion it was observed in electrophoresis of serum on new sponge that had been moistened but not filled with buffer that even after $45 \mathrm{~h}$ at $2 \mathrm{~mA}$ the spread of serum was minimal and protein remained in two sharp peaks close to the origin (Figure 3 ). This shows that the protein would not move as a result of diffusion in unfilled sponges.

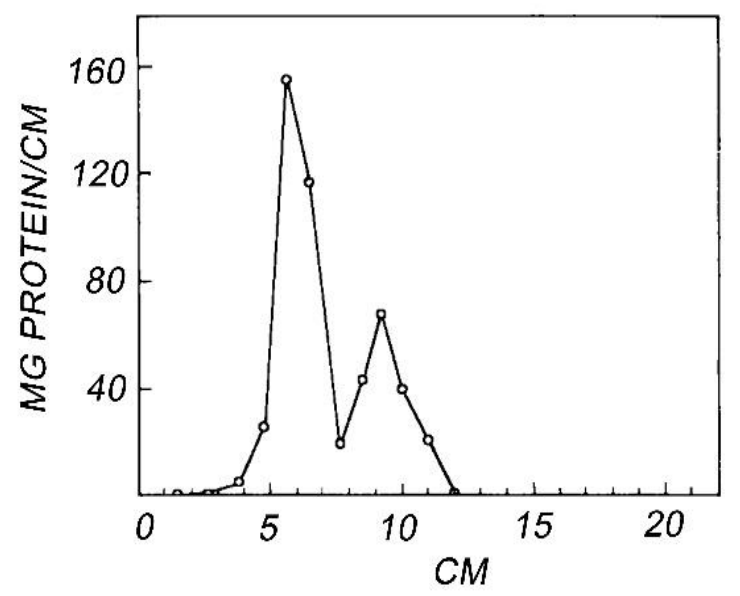

Fig3. Distribution of serum protein after electrophoresis on moist sponge. $4 \mathrm{ml}$ of serum were placed in a segment at 5.9-6.5 cm from the anodic end of the horizontal cell. The rest of the sponges were moistened with 0.083- $\mu$ Triscitrate, pH 8.8. $500 \mathrm{~V}$ were applied for $45 \mathrm{~h}$ at $2 \mathrm{~mA}$

\section{Zone Electrophoresis of Acid Phosphatase across a PH Gradient}

Acid phosphatase is a ubiquitous lysosomal enzyme that hydrolyses organic phosphates at an acid pH. Although the postpuberteral prostatic epithelial cell contains a uniquely high concentration of acid phosphatase, cellular components of bone, spleen, kidney, liver, intestine, and blood also contain this enzyme.

In the present experiment, migration horizontally along a pathway in which the concentration of hydrogen ion $\left(\mathrm{H}^{+}\right)$of the liquid varied from section to section was carried out using a preparation containing acid phosphatase (Figure 4). The sections were filled with acetate buffers ranging from $\mathrm{pH} 4.0$ to $\mathrm{pH} 6.0$ but all $0.03 \mathrm{M}$ in sodium acetate $\left(\mathrm{NaCH}_{3} \mathrm{COO}\right)$. Besides, the $\mathrm{pH}$ gradient there was therefore, a second gradient of acetate concentration at the start of the run. The enzyme at the beginning was placed at $\mathrm{pH} 4.4$ close to the region of maximum concentration of acetate which was at $\mathrm{pH}$ 4.0. The current was allowed to flow in the direction of increasing $\mathrm{pH}$ and decreasing concentration of acetate. Most of the protein migrated along with the activity away from the starting point at $\mathrm{pH} 4.4$ but material found at high acetate concentration and at $\mathrm{pH} 4.15$ was observed to have more than twice the initial specific activity (SA; units/mg). It was also noted that the pH decreased across the gradient during the course of the run. Although, the $\mathrm{pH}$ did not fall below 4.0 at any point, the range of the gradient narrowed during the run and at the end of experiment extended only from $\mathrm{pH} 4.0$ to $\mathrm{pH} 5.2$ within a region of the cell now occupied by protein. About $85 \%$ of the original activity was recovered. 


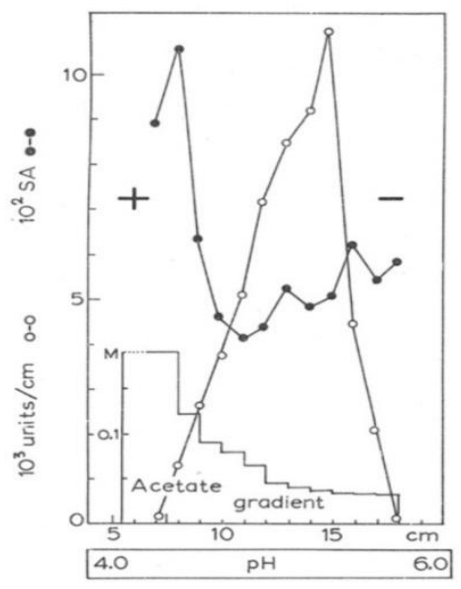

Fig4. Zone electrophoresis of a preparation containing prostatic acid phosphatase across a $p H$ gradient made with acetate buffer solutions. $3.7 \mathrm{ml}$ with $220 \mathrm{mg}$ of protein at 310 units $/ \mathrm{mg}$ at $\mathrm{pH} 4.4$ were placed at $9.5-10 \mathrm{~cm}$ from the cathodic end. $160 \mathrm{~V}$ were applied for $18 \mathrm{~h}$ with current rising from 8 to $16 \mathrm{~mA}$

Note: SA indicates to the specific activity (units of acid phosphatase activity/mg of protein)

As a consequence of finding that the protein richest in enzyme was located in the vicinity of high acetate concentration at $\mathrm{pH} 4.15$, the electrophoretic separation of enzyme in such a buffer solution was next attempted. A preparation with 1510 units/mg of protein served as starting material for this experiment. The sponges were filled with an acetic acid-sodium acetate buffer which was prepared by bringing a mixture of $10 \mathrm{ml}$ of $3 \mathrm{M}$ sodium acetate and $140 \mathrm{ml}$ of $1 \mathrm{M}$ acetic acid to $1 \mathrm{~L}$ with water. Although here, also, much of the activity moved ahead with the non-enzymic protein, a fraction was recovered containing protein with a specific activity of 5000 , a level of purity hitherto unequaled (Figure 5). $83 \%$ of the activity was recovered.

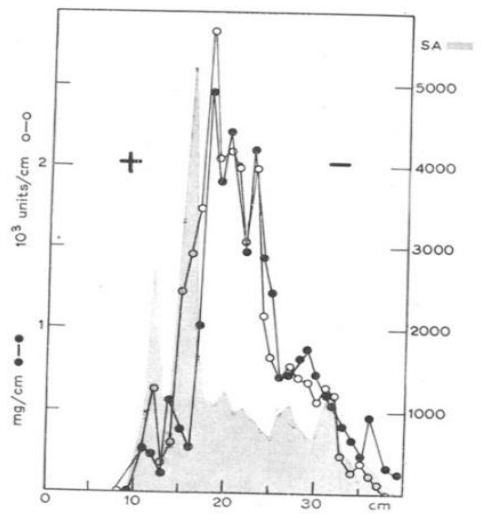

Fig5. A preparation of human prostatic acid phosphatase with $13.3 \mathrm{mg}$ of protein at 1500 units $/ \mathrm{mg}$ of protein was placed in a $0.5 \mathrm{~cm}$ wide section of sponge $11 \mathrm{~cm}$ from the anode. Sponges from 0 to $10 \mathrm{~cm}$ and from 31 to $49 \mathrm{~cm}$ contained $0.02 \mathrm{M}$ acetate buffer solution at $p H$ 4.15. All other sponges contained $0.2 \mathrm{M}$ acetate buffer at $p H$ 4.15. 300 V at an initial current of $2.2 \mathrm{~mA}$ were applied for $17 \mathrm{~h}$. Final current was $4.0 \mathrm{~mA}$. The shaded area indicates the specific activity (SA)

\section{Isoelectric Concentration of Protein in the Horizontal Cell, (Figure 6)}

The principle underlying separation in a combined $\mathrm{pH}$ and potential gradient is that when the current flows in the direction of increasing $\mathrm{pH}$, proteins within the field migrate to and remain at the $\mathrm{pH}$ corresponding to their respective isoelectric points. This technique has been applied before for the separation of mixtures in free solution [23-25] and using filter paper [26]. 


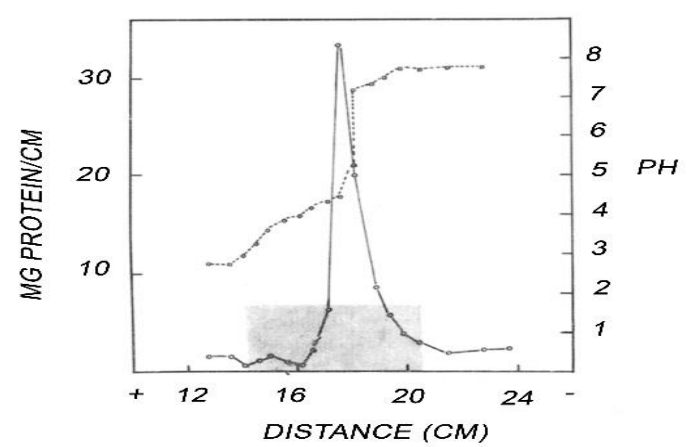

Fig6. Isoelectric concentration of albumin. Bovine crystalline albumin at $6.8 \mathrm{mg} / \mathrm{cm}$ (shaded area) was placed at the start over a $\mathrm{pH}$ range of 4-8. The solid line shows the distribution of albumin after $2 \mathrm{~h}$ at 250 V, 20-25 $\mathrm{mA}$. The broken line shows the $\mathrm{pH}$ at the end of the run

In order to test this principle in the horizontal sponge apparatus, experiments were done with albumin. Thus, in a typical experiment, approximately $100 \mathrm{mg}$ of crystalline bovine plasma albumin (Armour) in $25 \mathrm{ml}$ were dialyzed overnight at $5^{\circ}$ against distilled water. Fifteen 2-ml portions containing $7.12 \mathrm{mg}$ of albumin were each mixed with $1 \mathrm{ml}$ of a combination of two buffer solutions (B and C) of Eriksson [27] so as to obtain solutions of $3 \mathrm{ml}$ of albumin over a range of $\mathrm{pH}$ from 4 to 8. Solution B contained $300 \mathrm{ml} 0.1 \mathrm{~N} \mathrm{HCI}, 60 \mathrm{ml} \mathrm{H}_{2} \mathrm{O}$ and $100 \mathrm{ml}$ of Solution A per liter. Solution A consisted of 19.43 g sodium acetate $3 \mathrm{H}_{2} \mathrm{O}$ and 29.43 g sodium barbital in water in a final volume of $1 \mathrm{~L}$. Solution C was prepared by mixing $800 \mathrm{ml}$ of Solution A with $200 \mathrm{ml}$ of Solution B.

The anode electrode vessel contained $200 \mathrm{ml}$ of $\mathrm{B}$ and $20 \mathrm{ml}$ of a solution of $12 \% \mathrm{NaCl}$ in water; the cathode, $200 \mathrm{ml}$ of A and $20 \mathrm{ml}$ of $12 \% \mathrm{NaCl}$ solution. Sponge segments of the first $14 \mathrm{~cm}$ of the cell on the anodic side contained Solution B. Segments of $0.5 \mathrm{~cm}$ from $14 \mathrm{~cm}$ to $21 \mathrm{~cm}$ were each filled with the albumin-containing solutions arranged in order of increasing $\mathrm{pH}$. The remainder of the cell on the cathodic side was filled with segments containing Solution C. In such a system, the albumin moved from both sides of the $\mathrm{pH}$ range to peak at a position $17.8 \mathrm{~cm}$ from the anode. The $\mathrm{pH}$ of the solution at the position of the peak of protein was 4.4 (Figure 6).

A similar experiment was carried out with the center section containing buffered solutions of a preparation of human prostatic acid phosphatase assaying 1730 units/mg of protein (Figure 7). Under the conditions of this experiment employing the same buffers as in the previous experiment, the protein and the activity were distributed in two major peaks. Protein of the highest specific activity (twice that of the starting material) was not associated with these two peaks.

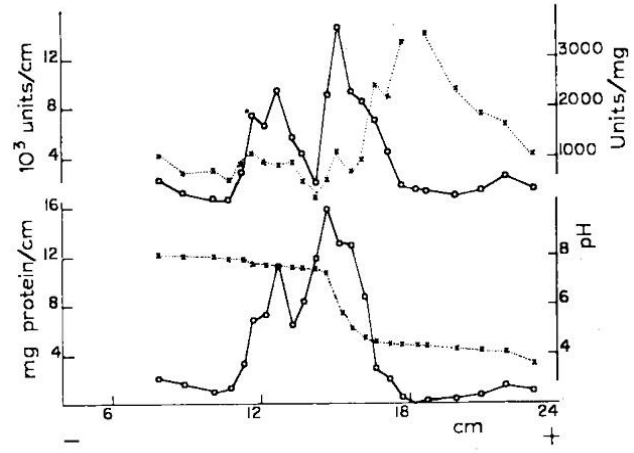

Fig7. Isoelectric fractionation of human prostatic proteins in veronal-acetate-HCl buffers. Protein was placed in the segments from 12 to $18 \mathrm{~cm}$. $200 \mathrm{~V}$ were applied for $5 \mathrm{~h}$. In the upper graphs the solid line shows the distribution of units; the dotted line, the specific activity. In the lower graphs, the solid line shows the distribution of protein; the dotted line, the final $\mathrm{pH}$. Some protein was lost in an insoluble precipitate that concentrated at $16 \mathrm{~cm}$ 
Polyurethane Foam in a Reliable Method for Electrophoretic Separation of Proteins

\section{Vertical Zone Electrophoresis of Serum}

With the vertical apparatus (Figure 1), particular attention had to be paid to differences in density that exist at the start or that might develop owing to the concentrating of a component during the course of the run. Therefore, care had to be taken to set up the column in such a manner not only that solutions of lesser density were placed above denser ones, but that the gradient was maintained throughout the run. Because the design of the apparatus permitted placement of the test material anywhere in the column, the protein may be so placed as to migrate upwards through a negative or downwards through a positive density gradient. The subject of density gradient electrophoresis in free solution has been explored in detail elsewhere [28-30].

Figure 8 shows the distribution of protein from pooled human serum which was placed near the bottom of the column and allowed to migrate upwards in the direction of decreasing density. In addition to the density gradient, the ionic strength increased in the same direction so that the protein moved up through a region of increasing conductivity. The effect of employing a gradient of ionic strength which increased in the direction of migration was to retard the advance of the fastest components. At the end of the experiment, boundary patterns were obtained on the material isolated from the starting point and from the forward edge of the migration. The difference in the patterns indicated that true electrophoretic separation had occurred.

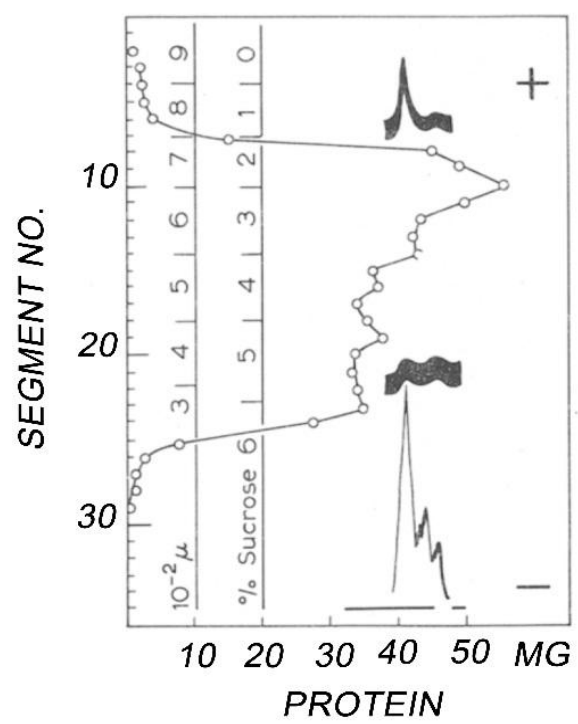

Fig8. Upward migration of serum in the vertical cell through gradients of ionic strength and density. Segment No. 23 originally contained $6.75 \mathrm{ml}$ of pooled serum that had been dialyzed against 0.03- $\mu$ veronal--citrate at $p H$ 8.7. Applied voltage was from 365 to $400 \mathrm{~V}$ for $39 \mathrm{~h}$ (15,000 V-h); the current, 15-19 mA. Boundary patterns are shown for pooled human serum (bottom) and for the contents of segments No. 23 (middle) and No.8 (top) at the end of the run

\section{Isoelectric Concentration and Fractionation of Serum Proteins in the Vertical Cell}

In the experiment shown in Figure 9, a steeper density gradient was used in order to accommodate the high protein concentration expected at the point where the serum albumin (Human serum albumin is the serum albumin found in human blood. It is the most abundant protein in human blood plasma; it constitutes about half of serum protein. It is produced in the liver. It is soluble in water and monomeric.) might accumulate. The $\mathrm{pH}$ range of the buffers and their composition in this experiment were the same as had been used in previous horizontal isoelectric concentration experiments, vide supra, except that the buffer solutions here contained varying amounts of sucrose $\left(\mathrm{C}_{12} \mathrm{H}_{22} \mathrm{O}_{11}\right)$. Protein precipitated in the region where it was expected to and actually did concentrate. This precipitate dissolved easily upon addition of a few $\mathrm{ml} \mathrm{of} 0.9 \% \mathrm{NaCl}$. Boundary electrophoresis patterns even of the adjacent fractions, 25 and 24, showed differences. No sponge contained 
protein corresponding to the serum gamma globulin (Globulin is any of a group of simple proteins soluble in salt solutions and forming a large fraction of blood serum protein. The three principal subsets of globulin are alpha globulin, beta globulin, and gamma globulin, which are distinguished by their respective degrees of electrophoretic mobility (alpha having the greatest and gamma having the least)) fraction. It was suspected that the gamma globulin must have moved out of the cell into the cathodic electrodes' vessel, which, in fact, was found to contain a substantial amount of protein.

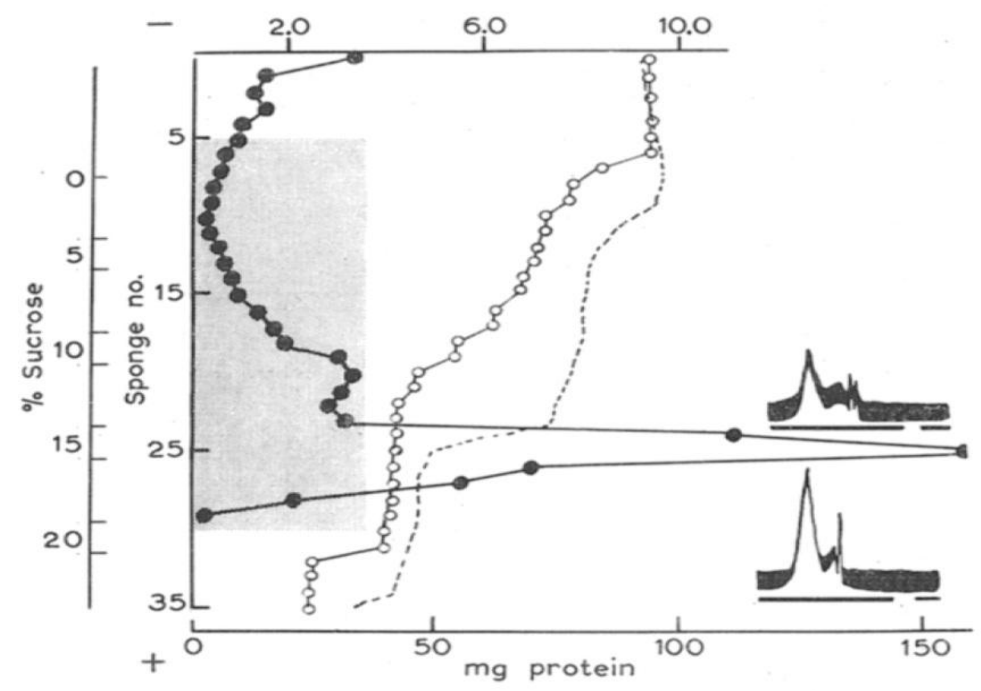

Fig9. Isoelectric fractionation of human serum in gradients of $\mathrm{pH}$ and density. Distribution of protein is indicated at the start by the shaded area and at end by the solid circles. Open circles indicate initial pH; dotted line equals final $p H$. Boundary patterns are given for the contents of segments No. 25 (lower) and 24 (upper)

\section{Discussion}

These investigations were undertaken in an effort to avoid contamination that resulted from the use of starch gel as a supporting medium in the purification of enzymes by zone electrophoresis. Extracts of the gel alone gave a positive reaction in the Lowry determination of protein $[31,32]$ as well as a positive iodine test for starch. The substitution of a supporting medium made of PU foam eliminated the problem of contamination of the product with starch and foreign protein and at the same time introduced certain other advantages inherent in the properties of the plastic material especially when arranged in segments.

One major advantage stemming from the use of pre-cut segments of flexible foam is the ease of recovery of each fraction at the end of the run. In addition, once a set of sponges had been cut to fit a cell, the set could be used repeatedly. The most attractive feature of working with this material, however, was the latitude it afforded in designing cells that varied in composition from section to section. Accordingly, it was possible to carry out electrophoretic experiments not only in the conventional manner in a medium of constant buffer composition throughout the cell but also in cells in which, for instance, the $\mathrm{pH}$, ionic strength and density were varied at will along the path of expected migration. It thus became possible to apply the segmental cell to the study of the electrophoretic behavior of mixtures of proteins when subjected to the influence of one or more gradients of these three types.

The sponge system was especially useful for performing experiments based on the technique of isoelectric fractionation which requires a $\mathrm{pH}$ gradient. The rather considerable concentration of protein which occurs as a consequence of the isoelectric technique is an attractive feature where the objective is simply one of concentrating dilute protein solution. 
Polyurethane Foam in a Reliable Method for Electrophoretic Separation of Proteins

From these experiments it is recommended that when dense solutions are investigated electrophoretically in the sponge system, the zones should be stabilized by employing a density gradient. This was done conveniently in the vertical cell. This objective is also met by the apparatus of Svenson and the one presented in Chang et al. [33]. It should be pointed out that the problem of droplets that form during zone electrophoresis in a sucrose density gradient [34-36] was not encountered in the sponge system.

The merits of foamed polymers other than the polyurethanes available to us have not been explored here. Besides the wide variety of polyurethane foams, there are other materials such as polyether and rubber which might offer unique advantages in electrophoretic studies especially in view of the possibility of synthesizing them to conform to the special requirements of electrophoresis investigations. Mitchell and Herzenberg [37] have reported on the use of foam rubber in zone electrophoresis and Marchis-Mouren et al. [38] has reported on the purification of hog pancreatic lipase using zone electrophoresis on a flexible plastic foam.

It should be noted that electrophoresis through a supporting medium of plastic foam involving migration through the holes of a lattice is quite different from electrophoresis through a medium of packed particles (e.g., starch granules). The sorption effects so pronounced in the latter process which may or may not assist the resolution of the components in the mixture should be minimal in an essentially open system. It is conceivable, however, that with a sponge matrix of the appropriate chemical composition beneficial sorption effects may be reintroduced into the system without sacrificing other desirable ones stemming from the peculiar features of the sponge material in electrophoresis.

Finally, it would appear that the segmental sponge system would offer some additional advantage should the investigation require the use of multiple gradients or especially one or more regions of marked discontinuity of composition within a density gradient. In this regard, it is not unlikely that one might incorporate adsorbents or ion exchange materials within one of the segments of sponge of the column if such an inclusion promised to promote the isolation of a desired product.

\section{CONCLUSION}

The use of polyurethane foam has removed the undesirable issues of starch and foreign protein contamination of the product during protein separation by electrophoresis and further had presented certain additional advantages inherent in the assets of the plastic material particularly when arranged in segments. Besides, based on isoelectric fractionation, the sponge system was feasible in the experiments regarded the variations of the $\mathrm{pH}$, ionic strength and density values. Therefore, we recommend electrophoresis based on plastic foam supporting medium which is a better choice than using a medium of packed particles (e.g., starch granules).

\section{REFERENCES}

1. Bonilla, S., \& Allen, D. G. (2018). Cationic proteins for enhancing biosludge dewaterability: A comparative assessment of surface and conditioning characteristics of synthetic polymers, surfactants and proteins. Sep Purif Technol, 191, 200-207. DOI: 10.1016/j.seppur.2017.08.048

2. Shanthirabalan, S., Chomilier, J., \& Carpentier, M. (2018). Structural effects of point mutations in proteins. Proteins: Struct Funct Bioinf, 86(8), 853-867. DOI: 10.1002/prot.25499

3. Rose, G. D. (2019). Ramachandran maps for side chains in globular proteins. Proteins: Struct Funct Bioinf, 87(5), 357-364. DOI: $10.1002 /$ prot.25656

4. Marina, M. L., Thorogate, R., \& Smith, N. W. (2006). A $150 \mu \mathrm{m}$ id packed column for the separation of soybean proteins by elution gradient $\mu$-HPLC: Simultaneous separation of soybean proteins from cereal and milk proteins. J Sep Sci, 29(7), 979-985. DOI: 10.1002/jssc.200500493 
Polyurethane Foam in a Reliable Method for Electrophoretic Separation of Proteins

5. Ichibangase, T., Yazawa, I., \& Imai, K. (2013). Efficient chromatographic separation of intact proteins derivatized with a fluorogenic reagent for proteomics analysis. Biomed Chromatogr, 27(11), 1520-1523. DOI: $10.1002 / \mathrm{bmc} .2952$

6. Adikane, H.V., Deshpande, P. P., Kapse, P. M., \& Chinchkar, P. A. (2018). Whey proteins separation: separation of whey proteins using modified cellulose fibre: an economical approach. Curr Biotechnol, 7(4), 329-337. DOI: $10.2174 / 2211550107666180423155103$

7. Aljerf, L., \& AlMasri, N. (2018). High resolution chromatography and sensitive retention: optimization of the experimental conditions for proteins extraction by preparative HPLC. J Progress Res Modern Phys Chem, 3(1), 97-103.

8. Chen, G., Zhitomirsky, I., \& Ghosh, R. (2019). Fast, low-pressure chromatographic separation of proteins using hydroxyapatite nanoparticles. Talanta, 199, 472-477. DOI: 10.1016/j.talanta.2019.02.090

9. Nicolás, P., Ferreira, M. L., \& Lassalle, V. (2019). A review of magnetic separation of whey proteins and potential application to whey proteins recovery, isolation and utilization. J Food Eng, 246, 7-15. DOI: 10.1016/j.jfoodeng.2018.10.021

10. Person, H., \& Överholm, T. (1990). Two-dimensional electrophoresis of membrane proteins: Separation of myelin proteins. Electrophoresis, 11(8), 642-648. DOI: 10.1002/elps.1150110812

11. Nath, S., Schütte, H., Hustedt, H., \& Deckwer, W. D. (1993). Application of continuous zone electrophoresis to preparative separation of proteins. Biotechnol Bioeng, 42(7), 829-835. DOI: 10.1002/bit.260420707

12. Semple-Rowland, S. L., Adamus, G., Cohen, R. J., \& Ulshafer, R. J. (1991). A reliable two-dimensional gel electrophoresis procedure for separating neural proteins. Electrophoresis, 12(4), 307-312. D0I: 10.1002/ elps.1150120414

13. Chakavart, B., \& Chakavart, D. (2008). Electrophoretic separation of proteins. J Vis Exp, 16, e758. DOI: $10.3791 / 758$

14. Geenen,S.,Jordaens, K., Castilho, R., \& Backeljau, T. (2003). Congruence between starch gel and polyacrylamide gel electrophoresis in detecting allozyme variation in pulmonate land slugs. Electrophoresis, 24(4), 622627. DOI: $10.1002 /$ elps.200390072

15. Aslebagh, R., Channaveerappa, D., Arcaro, K. F., \& Darie, C. C. (2018). Comparative two-dimensional polyacrylamide gel electrophoresis (2D-PAGE) of human milk to identify dysregulated proteins in breast cancer. Electrophoresis, 39(14), 1723-1734. DOI: 10.1002/elps.201800025

16. Tazawa, S., Kobayashi, K., Oyoshi, T., \& Yamanaka, M. (2017). Supramolecular gel electrophoresis of large DNA fragments. Electrophoresis, 38(20), 2662-2665. DOI: 10.1002/elps.201700223

17. Ren, F., Dong, D., Yu, B., Hou, Z. H., \& Cui, B. (2017). Rheology, thermal properties, and microstructure of heatinduced gel of whey protein-acetylated potato starch. Starch - Starke, 69(9-10), 1600344. DOI: 10.1002/ star.201600344

18. Li, H. C., Chernoff, J., Chen, L. B., \& Kirschonbaum, A. (1984). A phosphotyrosyl-protein phosphatase activity associated with acid phosphatase from human prostate gland. Eur J Biochem, 138(1), 45-51. DOI: 10.1111/ j.1432-1033.1984.tb07879.x

19. Ezeugwunne, I. P., \& Azikiwe, N. (2018). Evaluation of serum alkaline phosphatase and acid phosphatase in relation to Abo blood groups and genotypes of male blood donors in university college hospital Ibadan, Oyo State. Journal of Medical Science and Clinical Research, 6(1). DOI: 10.18535/jmscr/v6i1.118 
Polyurethane Foam in a Reliable Method for Electrophoretic Separation of Proteins

20. Bhivapure, R., Dalvi, S., Yeram, N., Patil, V., \& Abichandani, L. (2018). Study of prostate specific antigen, alkaline phosphatase and vitamin B12 in prostate cancer. Int J Biochem Res Rev, 22(2), 1-7. D0I: 10.9734/ ijbcrr/2018/42394

21. Rios, M. A. D. L. (2006). On the precision of experimentally determined protein folding rates and -values. Protein Sci, 15(3), 553-563. DOI: 10.1110/ps.051870506

22. Sridhar, K., Narayanan, M., \& Goswami, K. (2016). Measurement of total alkaline phosphatase activity in human serum using charcoal activated para-nitro phenyl phosphate. Int J Sci Res, 5(4), 1315-1317. DOI: $10.21275 / v 5 i 4 . n o v 162819$

23. Forciniti, D., Hall, C. K., \& Kula, M. R. (1991). Protein partitioning at the isoelectric point: Influence of polymer molecular weight and concentration and protein size. Biotechnol Bioeng, 38(9), 986-994. DOI: 10.1002/ bit.260380905

24. Wu, J., \& Pawliszyn, J. (1992). Application of capillary isoelectric focusing with universal concentration gradient detector to the analysis of protein samples. J Chromatogr A, 608(1-2), 121-130. DOI: 10.1016/00219673(92)87114-n

25. Weber, P. J. A., Weber, G., \& Eckerskorn, C. (2006). Native isoelectric focusing free-flow electrophoresis (IEFFFE) fractionation of crude protein mixtures. Cold Spring Harb Protoc, 2006(1), 4239. DOI: 10.1101/pdb. $\operatorname{prot} 4239$

26. Wu, Y., Yang, X., Wang, T., Wang, H., \& Li, Z. (2012). Identification of M protein from filter paper using serum protein and immunofixation electrophoresis. Am J Clin Pathol, 138(4), 604-608. DOI: 10.1309/ ajcpfy6hlit6hmqn

27. Eriksson, B. (2008). In-line application of electric field in capillary separation systems: Joule heating, $\mathrm{pH}$ and conductivity. Talanta, 75(1), 83-90. DOI: 10.1016/j.talanta.2007.10.032

28. Tulp, A., Verwoerd, D., \& Pieters, J. (1993). Application of an improved density gradient electrophoresis apparatus to the separation of proteins, cells and subcellular organelles. Electrophoresis, 14(1), 12951301. DOI: $10.1002 /$ elps.11501401198

29. Cole, K. D., Todd, P., Srinivasan, K., \& Dutta, B. K. (1995). Free-solution electrophoresis of proteins in an improved density gradient column and by capillary electrophoresis. J Chromatogr A, 707(1), 77-85. DOI: 10.1016/0021-9673(94)01245-a

30. Tran, F., \& Blaha, P. (2018). Density-gradient-free variable in exchange-correlation functionals for detecting inhomogeneities in the electron density. Phys Rev Mater, 2(12). DOI: 10.1103/physrevmaterials.2.120801

31. Maly, I. P., Toranelli, M., Crotet, V., \& Sasse, D. (1998). Ultrathin-layer zone electrophoresis of alcohol dehydrogenase in partly rehydrated polyacrylamide gels: An alternative to starch gel electrophoresis. Electrophoresis, 16(10), 1654-1658. DOI: 10.1002/elps.1150191022

32. Fjellström, K. E. (2009). Human complement components in starch gel electrophoresis. Acta Pathol Microbiol Immunol Scand, 59(1), 91-108. DOI: 10.1111/j.1699-0463.1963.tb01776.x

33. Chang, W. W. P., Hobson, C., Bomberger, D. C., \& Schneider, L. V. (2005). Rapid separation of protein isoforms by capillary zone electrophoresis with new dynamic coatings. Electrophoresis, 26(11), 2179-2186. DOI: 10.1002/elps.200410283

34. Zhang, M., Gong, X., \& Wen, W. (2009). Manipulation of microfluidic droplets by electrorheological fluid. Electrophoresis, 30(18), 3116-3123. DOI: 10.1002/elps.200900119 
Polyurethane Foam in a Reliable Method for Electrophoretic Separation of Proteins

35. Li, M., \& Li, D. (2017). Fabrication and electrokinetic motion of electrically anisotropic Janus droplets in microchannels. Electrophoresis, 38(2), 287-295. DOI: 10.1002/elps.201600310

36. Kahle, J., \& Wätzig, H. (2018). Determination of protein charge variants with (imaged) capillary isoelectric focusing and capillary zone electrophoresis. Electrophoresis, 39(20), 2492-2511. DOI: 10.1002/ elps.201800079

37. Mitchell, H. K., \& Herzenberg, L. A. (1957). Zone electrophoresis on sponge rubber. Anal Chem, 29(8), 12291229. DOI: $10.1021 / \mathrm{ac} 60128 \mathrm{a} 041$

38. Marchis-Mouren, G., Sarda, L., \& Desnuelle, P. (1959). Purification of hog pancreatic lipase. Arch Biochem Biophys, 83(1), 309-319. DOI : 10.1016/0003-9861(59)90036-0

Citation: Loai Aljerf, Farouk Dehmchi, Viet Ty Pham, Ala Eldin Choukaife, "Polyurethane Foam in a Reliable Method for Electrophoretic Separation of Proteins". American Research Journal of Chemistry, 3(1); pp:1-14.

Copyright (c) 2019 Loai Aljerf, Farouk Dehmchi, Viet Ty Pham, Ala Eldin Choukaife, This is an open access article distributed under the Creative Commons Attribution License, which permits unrestricted use, distribution, and reproduction in any medium, provided the original work is properly cited. 